\title{
Dydaktyka i wychowanie w szkołach wiejskich w okresie dwudziestolecia międzywojennego na przykładzie szkół powszechnych gminy Garbów
}

\begin{abstract}
Education and Upbringing in Country Schools in the Interwar Period as exemplified by Primary Schools in Garbów commune

The aim of this article is to present the processes of education and upbringing in the curricula for universal schools in the Interwar Period.

In the article, the example of primary schools is cited, operating in Garbów commune and the structure of the primary school network is described together with financial and material problems experienced in these schools and the methods of overcoming them. The teaching work of the teachers is presented with emphasis placed on the activity of school institutions and students organizations in the area. Attention is also paid to the significance of the achievements of the teaching and upbringing methods applied in primary schools in the Interwar Period.

The article is based on information obtained from sources made available by the National Archives in Lublin and chronicles stored in schools still operating in Garbów commune.
\end{abstract}

Keywords: Education, upbringing, primary education, Garbów commune

\section{Wstęp}

W 1918 r., kiedy Polska odzyskała niepodległość po ponad stu latach niewoli i walki z trzema zaborcami o tożsamość narodową i kulturową, jedną z istotnych kwestii stało się położenie podwalin pod budowę nowego systemu szkolnictwa. Wspomnieć przy tym trzeba, że było to bardzo trudne, gdyż na terenie każdego zaboru obowiązywały inne przepisy prawne, inne programy nauczania i wychowania, a przede wszystkim inny język wykładowy. Należało w związku z tym uchwalić akty prawne, które zapewniałyby jednolity system edukacyjny na terenie całego kraju. 
Nowe władze polskie szybko podjęły działania w tym zakresie, już w 1919 r. weszły w życie dwa dekrety regulujące sprawy oświatowe. Pierwszy z nich wprowadzał obowiązek szkolny dla każdego dziecka pomiędzy 7 a 14 rokiem życia ${ }^{1}$. Drugi dotyczył problemu kształcenia nauczycieli szkół powszechnych ${ }^{2}$. W następnych latach ustanawiano kolejne przepisy prawne porządkujące dotychczasowy stan rzeczy i wprowadzające nowe regulacje w polskiej edukacji. Najważniejsze z nich to: ustawa o tymczasowym ustroju władz szkolnych z 1920 r. (w myśl której powstały okręgi szkolne nadzorowane przez kuratorów) ${ }^{3}$, Konstytucja Rzeczypospolitej Polskiej z marca 1921 roku (stanowiąca o bezpłatnej i obowiązkowej nauce w szkołach powszechnych oraz o konieczności uczestniczenia w lekcjach religii do ukończenia 18 roku życia $)^{4}$, ustawa o zakładaniu i utrzymywaniu publicznych szkół powszechnych oraz ustawa o budowie publicznych szkół powszechnych (obie z 1922 r.) $)^{5}$, wreszcie ustawa o ustroju szkolnictwa z 1932 r. (zgodnie z którą wprowadzono 7-letni okres nauki w szkołach powszechnych przy trzystopniowym podziale tych placówek na 4-letnie szkoły pierwszego stopnia, 6-letnie szkoły drugiego stopnia i 7-letnie szkoły trzeciego stopnia) ${ }^{6}$.

\section{Powstanie sieci szkolnej na terenie gminy Garbów}

Przez wszystkie lata dwudziestolecia międzywojennego na terenie dużych miast, małych miasteczek i maleńkich wsi powstawały szkoły powszechne, kształcące dzieci i młodzież na poziomie podstawowym. Tworzenie tych placówek oraz ich działalność opierały się na wspomnianych wyżej przepisach prawnych wydawanych przez ówczesne władze oświatowe.

Nie inaczej było na terenie gminy garbowskiej, gdzie zgodnie z przepisami oświatowymi starano się zapewnić dostęp do nauki każdemu dziecku objętemu obowiązkiem nauki w szkole powszechnej . Można stwierdzić, że sieć szkolna była tu bardzo rozbudo-

${ }^{1}$ M. Balcerek, Rozwój opieki nad dzieckiem w Polsce w latach 1918-1939, Warszawa 1978, s. 109; W. Grabowska, Szkolnictwo powszechne w Polsce w latach 1932-1939, Wrocław-Warszawa-Kraków-Gdańsk 1976, s. 18-19; P. Mazur, Szkolnictwo na Lubelszczyźnie w świetle prasy lokalnej, 1918-1939, Lublin 2004, s. 59.

${ }^{2}$ W. Grabowska, Szkolnictwo powszechne..., s. 19.

${ }_{3}$ M. Danielski, Ustawodawstwo Szkolne i Prawo Nauczycielskie, Lwów-Warszawa-Poznań 1932, s. 38; Ustawa z dnia 4 czerwca 1920 roku o tymczasowym ustroju władz szkolnych (Dz. U. z 1920 r. $\mathrm{Nr} 50$, poz. 304).

${ }^{4}$ M. Balcerek, Rozwój opieki..., s. 106.

${ }^{5}$ W. Grabowska, Szkolnictwo powszechne..., s. 19; P. Mazur, Szkolnictwo na Lubelszczyźnie..., s. 60.

${ }^{6}$ Archiwum Zespołu Szkół w GarbowieI (AZSG), Kronika Szkolna Publicznej Szkoły Powszechnej w Garbowie; AZSG, Księga Protokołów Nauczycielskich Konferencji Gminnych Gminy Garbów (1924-1935); Archiwum Zespołu Szkół w Przybysławicach (AZSP), Kronika Szkolna Publicznej Szkoły Powszechnej w Przybysławicach; M. Balcerek, Rozwój opieki..., s. 106; M. Danielski, Ustawodawstwo Szkolne..., s. 116; Dolnośląska Biblioteka Cyfrowa (DBC), Statut Publicznych Szkół Powszechnych Siedmioletnich, s. 3-5; Ustawa z dnia 11 marca 1932 r. o ustroju szkolnictwa (Dz.U. 1932 nr 38 poz. 389).

7 Dekret o obowiązku szkolnym z 7 lutego 1919 roku (Dz.U. 1919 nr 14 poz. 147). 
wana. W jej ramach funkcjonowało bowiem aż 11 szkół powszechnych o różnym stopniu organizacyjnym. Placówki te mieściły się we wsiach: Garbów, Bogucin, Przybysławice, Wola Przybysławska, Borków, Gutanów, Karolin, Leśce, Ługów, Moszenki i Piotrowice Wielkie ${ }^{8}$.

Najstarszą z nich jest szkoła w Garbowie. Historia tej placówki sięga 1860 r., w którym utworzona została szkoła elementarna9. W 1918 r. natychmiast została ona przekształcona w szkołę publiczną ${ }^{10}$. Początkowo była to szkoła 3-klasowa pierwszego stopnia. W roku szkolnym 1933/34 stała się szkołą 5-klasową drugiego stopnia, a dwa lata później placówka ta otrzymała status 7-letniej publicznej szkoły powszechnej trzeciego stopnia $^{11}$.

Kolejną szkołą powszechną o najwyższym stopniu organizacyjnym była Publiczna Szkoła Powszechna w Przybysławicach. Powstała ona w 1926 r. ${ }^{12}$, a wraz z kolejnym rokiem szkolnym1927/28 zaczęła funkcjonować jako szkoła powszechna trzeciego stopnia, w której w ciągu siedmiu lat realizowano cały, obowiązujący wówczas nauczycieli i uczniów tego typu placówek, ministerialny program edukacyjny ${ }^{13}$.

Wymienione wyżej szkoły powszechne w Bogucinie, Woli Przybysławskiej, Borkowie, Gutanowie, Karolinie, Leścach, Ługowie, Moszenkach i Piotrowicach Wielkich powstały na gruncie szkół prywatnych i posiadały niższe stopnie organizacyjne. Za wyjątkiem placówki w Bogucinie, która w 1939 r. stała się szkołą 6-letnią (naukę w zakresie klasy siódmej uczniowie kontynuowali w szkole w Garbowie) ${ }^{14}$, były one 3-letnimi szkołami pierwszego stopnia ${ }^{15}$. Osobą odpowiedzialną za prawidłowe funkcjonowanie szkoły natomiast był jej kierownik. Wspomnieć trzeba, że w szkołach pierwszego stopnia, w których zajęcia dla wszystkich klas prowadził jeden nauczyciel, to właśnie jemu powierzano stanowisko kierownicze ${ }^{16}$.

\footnotetext{
${ }^{8}$ AZSG, Księga Protokołów.

9 Archiwum Państwowe w Lublinie (APL), Sygn. 35/525/0/3146, Zespół: Dyrekcje Szkolne, Akta Lubelskiej Dyrekcji Szkolnej, Naczelnik Szkoły w Garbowie, gminy Garbów w powiecie Nowo-Aleksandryjskim, 1865-1866; 150 lat Szkoty w Garbowie, Garbów 2010, s. 6-7.

${ }^{10}$ AZSG, Kronika Szkolna Publicznej Szkoły Powszechnej w Garbowie; B. Sałęga, Schola Publica Garboviensis (odc. III), „Głos Garbowa” 12(1992), s. 4; 150 lat Szkoły w Garbowie, s. 7.

11 Ibidem; 150 lat Szkoly $w$ Garbowie, s. 7.

12 AZSP, Kronika Szkolna Publicznej Szkoły Powszechnej w Przybysławicach; H. Stępniak, Szkoła w Przybystawicach (odcinek I), „Głos Garbowa” 10(1994), s. 3.

13 R. Wójcik, Historia Cukrowni „, Garbów”, Lublin 2010, s. 196.

14 Ibidem.

${ }^{15} \mathrm{http}$ ://www.jastkow.pl/index.php?option=com_content\&view=article\&id=66\&Itemid=91, (13.03.2012); APL, Sygn. 35/732/0/2/90, Zespół: Inspektorat Szkolny w Puławach, Akta Szkoły Podstawowej w Woli Przybysławskiej; AZSG, Księga Protokołów Nauczycielskich Konferencji Gminnych Gminy Garbów (1924-1935); AZSG, Kronika Szkolna Publicznej Szkoły Powszechnej w Garbowie; M. Wartacz, Kilka słów o Gutanowie - dawnym i współczesnym, odc. I, „Głos Garbowa” 1(1997), s. 6-7; M. Wartacz, Kilka słów o Gutanowiedawnym $i$ współczesnym, odc. II, „Głos Garbowa” 2(1997), s. 6-7; M. Wartacz, Tomasz Wincenty Grabowski, w: Siedziby ziemiańskie w krajobrazie ziemi garbowskiej, pod red. H. Stępniak, Garbów 2008, s. 291-298; http://www.jastkow.pl/index.php?option=com_content\&view=article\&id=66\&Itemid=91, (13.03.2012).

${ }^{16}$ DBC, Statut Publicznych Szkół Powszechnych Siedmioletnich, s. 7-8.
} 
Nauka w szkołach powszechnych była bezpłatna ${ }^{17}$. Koszty utrzymania szkół ponosił Skarb Państwa i, w przypadku szkół garbowskich, Gmina Garbów. Wspomnieć jednakże trzeba też o szerokiej aktywności rodziców uczniów i miejscowych instytucji społecznych w kwestii finansowego wspierania tychże placówek. Były to dodatkowe fundusze w różnym stopniu powiększające skromne budżety szkolne ${ }^{18}$, a pochodziły głównie z zysków osiąganych ze sprzedaży biletów na przedstawienia szkolne, czy też z loterii fantowych. Zdobyte w ten sposób środki pieniężne przeznaczano głównie za zakup umeblowania i pomocy naukowych ${ }^{19}$.

\section{Realizowanie programu nauczania i wychowania w szkołach powszechnych gminy Garbów}

Publiczne szkoły powszechne działające na terenie gminy garbowskiej, podobnie jak inne szkoły tego typu w Polsce, za podstawę swojej pracy przyjęły wypełnianie szeregu zadań związanych z nauczaniem i wychowaniem dzieci i młodzieży.

\section{Realizacja celów dydaktycznych}

We wszystkich szkołach powszechnych na terenie II Rzeczypospolitej obowiązywał program nauczania opracowany i zatwierdzony przez specjalistów z Ministerstwa Wyznań Religijnych i Oświecenia Publicznego. Zgodnie z wytycznymi zawartymi w tym programie dzieci i młodzież uczestniczyły w zajęciach języka polskiego, rachunków, rysunku, robót ręcznych, ćwiczeń cielesnych oraz religii. Począwszy od klasy trzeciej uczniowie zdobywali wiedzę z historii, geografii i przyrody. Szóstoklasiści natomiast uczyli się dodatkowo chemii i fizyki ${ }^{20}$.

Nauczyciele gminy garbowskiej nie ograniczali się w swojej pracy dydaktycznej jedynie do przekazywania informacji na lekcjach przedmiotowych. Równie istotne było dla nich wzbudzenie zainteresowania uczniów daną dziedziną wiedzy tak, aby ci chcieli ją dalej pogłębiać. Realizacji tego celu służyły koła samokształceniowe, biblioteki szkolne oraz wycieczki krajoznawcze.

17 Ibidem, S. 3.

${ }_{18}$ AZSG, Kronika Szkolna Publicznej Szkoły Powszechnej w Garbowie; AZSG, Księga Protokołów Nauczycielskich Konferencji Gminnych Gminy Garbów (1924-1935); AZSP, Kronika Szkolna Publicznej Szkoły Powszechnej w Przybysławicach; M. Danielski, Ustawodawstwo Szkolne, s. 25-26; Ustawa z dnia 17 lutego 1922 r. o zakładaniu i utrzymywaniu publicznych szkół powszechnych (Dz.U. 1922 nr 18 poz. 144).

19 AZSG, Kronika Szkolna Publicznej Szkoły Powszechnej w Garbowie.

${ }^{20}$ AZSG, Księga Protokołów Nauczycielskich Konferencji Gminnych Gminy Garbów (1924-1935); AZSP, Kronika Szkolna Publicznej Szkoły Powszechnej w Przybysławicach; DBC, Statut Publicznych Szkół Powszechnych Siedmioletnich, s. 13. 
Na podstawie materiałów źródłowych można stwierdzić, że koła samokształceniowe funkcjonowały jedynie w szkole powszechnej w Przybysławicach. Przypuszczać należy, iż stało się tak z powodu opóźnienia, jakie nastąpiło w związku z otwarciem szkoły, co oczywiście spowodowało również zaległości w realizacji programu nauczania. Jedynym wyjściem w tej sytuacji wydawało się być utworzenie właśnie kół samokształceniowych. Była to trafna decyzja podjęta przez ówczesnego kierownika szkoły Mariana Gietko. Pozwoliło to bowiem na szybkie i dokładne uzupełnienie wiedzy z konkretnych przedmiotów. Ale nie tylko. Koła samokształceniowe dawały uczniom również możliwość zarówno utrwalenia, jak i poszerzenia posiadanego przez nich zasobu wiadomości ${ }^{21}$.

Podstawą funkcjonowania kół samokształceniowych w przybysławickiej szkole powszechnej były regulaminy ${ }^{22}$. W myśl tych przepisów każde Koło Samokształceniowe posiadało zarząd. W jego skład wchodził przewodniczący, sekretarz, czytelnik książek, czytelnik pism oraz redaktor gazetki. Opiekę merytoryczną i wychowawczą nad kołami powierzano gronu pedagogicznemu, przy czym jeden nauczyciel sprawował nadzór nad jednym kołem ${ }^{23}$.

Koła samokształceniowe skupiały uczniów klasy czwartej, piątej, szóstej i siódmej. Praca kół polegała na tym, że raz lub dwa razy w tygodniu uczniowie spotykali się na tzw. posiedzeniach, podczas których starali się uzupełnić wiedzę z tego zakresu materiału naukowego, który nie został zrealizowany na zajęciach lekcyjnych z konkretnego przedmiotu. Ciekawym rozwiązaniem było tutaj wykorzystanie takiego sposobu prezentacji danego tematu, jakim jest referat. Warto przy tym wspomnieć, że najbardziej oczekiwane i najlepiej oceniane były referaty wygłaszane z pamięci, z zachowaniem dokładności wymowy. Opracowywali je sami uczniowie na podstawie materiałów źródłowych dostarczanych im przez nauczycieli, bądź też opiekuna danego Koła. Kładziono nacisk na to, aby referat był jak najlepiej przygotowany nie tylko pod względem rzeczowym, ale też ze szczególną dbałością o zachowanie zasad ortografii, gramatyki oraz o poprawność stylistyczną. Funkcję opiniotwórczą w tej kwestii pełnili uczniowie należący do danego Koła. Po wygłoszeniu lub odczytaniu referatu następowała dyskusja ${ }^{24}$.

$\mathrm{Na}$ każdym spotkaniu wysłuchiwano z reguły dwóch referatów, przy czym każdy $\mathrm{z}$ nich dotyczył zagadnień $\mathrm{z}$ innego przedmiotu ${ }^{25}$.

Praca, jaką wykonywali uczniowie skupieni w kołach samokształceniowych nie ograniczała się jednak jedynie do przygotowywania referatów i dzielenia się w ten sposób posiadanymi informacjami z kolegami i koleżankami. Wręcz przeciwnie. Stale pogłębia-

\footnotetext{
21 AZSP, Kronika Szkolna Publicznej Szkoły Powszechnej w Przybysławicach.

${ }^{22}$ Ibidem.

23 Ibidem.

${ }^{24}$ Ibidem.

${ }^{25}$ Ibidem.
} 
li oni swoją wiedzę przez czytanie książek i czasopism. Te ostatnie były często prenumerowane przez uczniów ${ }^{26}$.

Podjęcie przez uczniów pracy samokształceniowej przynosiło również efekty w postaci gazetek szkolnych i młodzieżowych. Obowiązki, jakie wynikały z pełnienia funkcji redaktorów, edytorów oraz wydawców tych periodyków kształtowały u uczniów umiejętność samodzielnego myślenia, a także odpowiedzialność, pracowitość i zaradność ${ }^{27}$.

Można z całą pewnością stwierdzić, że działalność kół samokształceniowych opierała się głównie na rozwijaniu zdolności intelektualnych dzieci i młodzieży. Niemniej ważną kwestią było też wyrobienie u uczniów umiejętności pracy indywidualnej i grupowej, a w konsekwencji również zmysłu społecznego i woli ${ }^{28}$.

\section{Biblioteki szkolne}

Realizacja celów dydaktycznych, jakie stawiali przed sobą nauczyciele szkół powszechnych w gminie Garbów wymagała ścisłej współpracy kadry pedagogicznej z bibliotekami szkolnymi. Stanowiły one uzupełnienie dla pracy dydaktycznej prowadzonej w ramach kół samokształceniowych funkcjonujących w szkole powszechnej w Przybysławicach i pełniły niewątpliwie dużą rolę $\mathrm{w}$ realizacji programu nauczania również w pozostałych szkołach gminy Garbów. Głównym celem działalności bibliotek szkolnych było kształtowanie u uczniów postawy zamiłowania do czytania książek. Osiągano to przede wszystkim przez dokładne dobranie lektur do wieku i poziomu intelektualnego dziecka. Zadania tego podejmował się zawsze jeden z nauczycieli prowadzący bibliotekę szkolną ${ }^{29}$. W szkole przybysławickiej kierownik biblioteki odpytywał uczniów z przeczytanych książek. Dzieci z klas II-V najczęściej przedstawiali nauczycielowi treść lektury, opowiadając o bohaterach danej książki i wydarzeniach w niej opisanych. Uczniowie uczęszczający do klas starszych dokonywali ustnej charakterystyki postaci, a także pisali rozprawki i wypracowania ${ }^{30}$. W ten sposób, wykorzystując zamiłowanie młodzieży do czytania, realizowano cele nauczania języka polskiego w zakresie ugruntowania u uczniów znajomości ortografii i gramatyki języka polskiego, a także wyrabiano u nich poprawny styl przenoszenia swoich myśli na papier.

Praca każdej biblioteki opierała się na współpracy nauczyciela pełniącego funkcję kierowniczą i uczniów wykonujących wszystkie obowiązki związane z wypożyczaniem i odbieraniem książek od swych koleżanek i kolegów ${ }^{31}$.

\footnotetext{
${ }^{26}$ Ibidem.

27 Ibidem.

28 Ibidem.

29 Ibidem.

${ }^{30}$ Ibidem.

${ }^{31}$ Ibidem.
} 
W ciekawy sposób funkcjonowała biblioteka szkolna w Przybysławicach. Nadzorującym pracę biblioteki była, podobnie jak w innych szkołach, osoba z grona pedagogicznego powołana do tego zadania. Nauczyciela w jego obowiązkach wspierała Sekcja Biblioteczna złożona z: przewodniczącego, sekretarza, skarbnika i komisji klasowych. W gronie tych komisji znajdowali się uczniowie, którzy jako reprezentanci poszczególnych oddziałów szkolnych raz w tygodniu wypożyczali potrzebne książki dla kolegów i koleżanek z tej samej klasy. Zobowiązani byli przy tym do prowadzenia kart książek i kart czytelników, a także do kontroli stanu książek zwracanych przez wypożyczających. $\mathrm{Na}$ koniec każdego roku szkolnego prowadzący bibliotekę (nauczyciel i uczniowie) sporządzali sprawozdanie statystyczne, odzwierciedlający stan czytelnictwa w przybysławickiej szkole, które zawierało dane odnośnie do liczby książek znajdujących się w zasobie bibliotecznym, liczby przeczytanych egzemplarzy i liczby uczniów korzystających ze zbiorów biblioteki ${ }^{32}$. W ten sposób uczniowie nie tylko rozwijali swoje umiejętności matematyczne, lecz także pogłębiali zakres swojej wiedzy o elementy statystyki.

Materiały źródłowe nie pozostawiają wątpliwości, że biblioteka szkolna istniała w każdej, nawet najmniejszej szkole działającej na terenie gminy garbowskiej ${ }^{33}$. Oczywiście, biblioteki w 3-letnich szkołach o jednym nauczycielu nie mogły się w żaden sposób równać z najwyżej zorganizowanymi szkołami trzeciego stopnia, jakie istniały w Garbowie i Przybysławicach. Mimo to spełniały swoją dydaktyczną funkcję na miarę swoich możliwości.

Zasoby poszczególnych bibliotek stale się powiększały. Nabywano kolejne książki. Środki pieniężne na ich zakup pochodziły z loterii fantowych urządzanych wspólnymi siłami nauczycieli, uczniów i rodziców. Uzupełnieniem tych funduszy były dochody z przedstawień wystawianych przez społeczność szkolną z okazji różnych rocznic i świąt patriotycznych i państwowych. Ponadto w kalendarium każdego roku szkolnego wpisany był Miesiąc Książki, w czasie którego również zbierano pieniądze na potrzeby poszczególnych bibliotek szkolnych ${ }^{34}$.

Zbiory biblioteczne to nie tylko książki, ale również czasopisma. Dlatego też starano się prenumerować różne periodyki przeznaczone dla dzieci i młodzieży. W okresie dwudziestolecia międzywojennego uznaniem cieszyły się takie czasopisma jak: „Mały Płomyk” (adresowany do najmłodszych uczniów), „Płomyczek” (dla dzieci uczęszczających do klas II-IV), „Płomyk” (dla uczniów oddziałów IV-VII) oraz „Iskry” i „Młody Zawodowiec" (dla młodzieży z klasy VI i VII). Przypuszczać należy, że największe grono czytelników tych periodyków stanowiły dzieci z ubogich rodzin, których nie stać było na kupno czasopism. Uczniowie mający zamożniejszych rodziców zakładali bowiem pry-

32 Ibidem.

33 APL, Sygn. 35/732/0/2/53,Zespół: Inspektorat Szkolny w Puławach, Akta Szkoły Podstawowej w Leścach, 1944-1950; B. Sałęga, Schola Publica Garboviensis (odc. III), „Głos Garbowa” 12(1992), s. 4.

${ }^{34}$ AZSG, Kronika Szkolna Publicznej Szkoły Powszechnej w Garbowie; Księga Protokołów Nauczycielskich Konferencji Gminnych Gminy Garbów (1924-1935); AZSP, Kronika Szkolna Publicznej Szkoły Powszechnej w Przybysławicach; B. Sałęga, Schola Publica Garboviensis (odc. III), „Głos Garbowa” 12(1992), s. 4; B. Sałęga, Schola Publica Garboviensis (odc. IV), „Głos Garbowa” 1(1993), s. 5. 
watne prenumeraty ${ }^{35}$. Niestety nie ma informacji odnośnie do tego, czy każda biblioteka szkolna w gminie Garbów prowadziła prenumeratę czasopism. Wiadomo jedynie, że dostęp do nich mieli uczniowie siedmioklasówki w Garbowie i Przybysławicach.

W tym miejscu należy wspomnieć o innej istotnej kwestii dotyczącej zwłaszcza mniejszych bibliotek szkolnych. Postanowiono bowiem, że w pierwszą niedzielę każdego miesiąca dokonywana będzie wymiana książek pomiędzy wszystkimi bibliotekami szkolnymi w gminie Garbów. Pierwsza tego typu akcja miała miejsce w roku szkolnym 1925/26 $6^{36}$. Największe znaczenie miało to w przypadku małych szkół, które z reguły dysponowały również niewielkim budżetem na cele biblioteczne. Nie ulega wątpliwości, że dzięki temu posunięciu dzieci miały dostęp do szerszego zakresu lektur i literatury pięknej. Podkreślić jednakże należy, że celem rozwoju czytelnictwa wśród dzieci i młodzieży szkolnej był nie tylko wzrost liczby przeczytanych książek i czasopism. O wiele większą wartość miało wzbogacenie wiedzy uczniów z zakresu różnych dziedzin nauki. Nie bez znaczenia była też możliwość kształtowania przez odpowiednią lekturę woli i uczuć dzieci i młodzieży ${ }^{37}$.

\section{Wycieczki krajoznawcze}

Stacjonarny tryb nauczania, jaki reprezentowały koła samokształceniowe i biblioteki szkolne uzupełniały wycieczki krajoznawcze. Były one bardzo ważnym elementem pracy dydaktycznej nauczycieli szkół powszechnych na terenie całej Polski. Służyły one bowiem przede wszystkim kształtowaniu poczucia piękna i uczuć patriotycznych wśród dzieci i młodzieży szkolnej.

Organizując wycieczki krajoznawcze, nauczyciele zwracali szczególną uwagę na ich aspekt historyczny i geograficzny. Dokładnie planowali trasę przejazdu, a także wyznaczali zabytki i miejsca pamięci, które mieli odwiedzić z uczniami ${ }^{38}$. Grono pedagogiczne gminy Garbów dokładało wszelkich starań, aby uczniowie mogli zwiedzić zarówno najbliższą okolicę, jak i miasta znacznie oddalone od ich miejsca zamieszkania. Dzieci udawały się zatem na wycieczki jednodniowe do Garbowa i Jastkowa, a także do Lublina, Puław, Kazimierza, Nałęczowa, Dęblina i Warszawy. Oprócz tych bliskich i krótkich wyjazdów organizowano wycieczki kilkudniowe do Krakowa, Wieliczki i Zakopanego, do Gdańska i Gdyni oraz na Hel, a także do Poznania i na Śląsk ${ }^{39}$.

35 AZSP, Kronika Szkolna Publicznej Szkoły Powszechnej w Przybysławicach.

36 AZSG, Kronika Szkolna Publicznej Szkoły Powszechnej w Garbowie.

${ }^{37}$ AZSP, Kronika Szkolna Publicznej Szkoły Powszechnej w Przybysławicach; Archiwum Akt Nowych w Warszawie (AAN), Sygn. 712, Zespół: Związek Zawodowy Cukrowni, Cukrownia Garbów - Szkoła.

38 AZSP, Kronika Szkolna Publicznej Szkoły Powszechnej w Przybysławicach.

39 Ibidem; AZSG, Kronika Szkolna Publicznej Szkoły Powszechnej w Garbowie; B. Sałęga, Schola Publica Garboviensis (odc. III), „Głos Garbowa” 12(1992), s. 4; B. Sałęga, Schola Publica Garboviensis (odc. IV), „Głos Garbowa” 1(1993), s. 5; W. Kula, Wspomnienia o Marianie Gietce w 55. rocznice śmierci, „Głos Garbowa" 6(2004), s. 11; W. Kula, Wspomnienia o Marianie Gietce w 55. rocznice śmierci, Wspomnienia Bronisławy Dzierżyc, „Głos Garbowa” 7-8(2004), s. 13. 
Środki pieniężne na pokrycie kosztów tych wyjazdów pochodziły z funduszu wycieczkowego zasilanego głównie oszczędnościami uczniów oraz dochodami z przedstawień szkolnych i loterii fantowych. W sytuacji, gdy zebrana przez dzieci kwota nie była wystarczająca, brakującą kwotę dokładały Koła Rodzicielskie lub Urząd Gminy Garbów. Nie były to jednak częste przypadki. Z reguły koszty wycieczki pokrywane były częściowo ze zgromadzonych przez uczniów funduszy, a resztę dokładali rodzice uczniów lub też sami uczniowie ze swoich osobistych oszczędności ${ }^{40}$.

Wycieczki upamiętniano za pomocą fotografii wklejanych później do kronik szkolnych, zostawiając w ten sposób informacje dla przyszłych roczników szkół powszechnych garbowskiej gminy do miejsc, w które wyjeżdżali ich starsi koledzy i koleżanki.

\section{Realizacja celów wychowawczych}

Obowiązki nauczycieli nie ograniczały się jedynie do przekazywania wiedzy z zakresu różnych przedmiotów. Dydaktyka musiała iść w parze z wychowaniem młodego pokolenia. W szkołach powszechnych gminy Garbów, podobnie jak w innych placówkach edukacyjnych w Polsce, dążono przede wszystkim do przygotowania uczniów do życia zarówno w lokalnej społeczności, jak i w społeczeństwie obywatelskim. Starano się wpoić im poczucie obowiązku wobec społeczeństwa polskiego i chęć podejmowania działań na jego rzecz.

W ramach realizacji celów wychowawczych przekazywano uczniom prawidłowe wzorce osobowościowe, wzorce dobrego zachowania. Wpajano szacunek i posłuszeństwo wobec rodziców, nauczycieli i przyszłych przełożonych. Wyrabiano u nich zamiłowanie do porządku zarówno w szkole, jak też w domu i w najbliższym otoczeniu ${ }^{41}$.

Program wychowawczy, który wynikał z przepisów ministerialnych, realizowano wykorzystując bezpośredni wpływ na uczniów tak na terenie szkoły, jak i poza nią. W tym drugim przypadku należało utrzymywać stały kontakt z rodzicami lub opiekunami wychowanka. Niebagatelne znaczenie miał też sam proces dydaktyczny. Ponadto każdy nauczyciel był zobowiązany do wspomagania samowychowania swoich podopiecznych. Miał współuczestniczyć w organizowaniu życia szkolnego ${ }^{42}$.

Bezpośredni wpływ na uczniów nauczyciele wywierali przede wszystkim przez własną postawę wobec życia, innych ludzi i powierzonych im obowiązków. Wskazane było, aby okazywali życzliwość swoim wychowankom. Oczekiwano również od nauczycieli, żeby mieli baczenie na zdrowie i bezpieczeństwo uczniów, a w związku z tym także na warunki w jakich mieszkają i ich sytuację rodzinną. Nauczyciele musieli zatem wzbudzać zaufanie rodziców i posiadać umiejętność przekonania ich do aktywnego włą-

\footnotetext{
40 AZSP, Kronika Szkolna Publicznej Szkoły Powszechnej w Przybysławicach.

${ }^{41}$ AZSG, Kronika Szkolna Publicznej Szkoły Powszechnej w Garbowie; AZSP, Kronika Szkolna Publicznej Szkoły Powszechnej w Przybysławicach.

42 DBC, Statut Publicznych Szkół Powszechnych Siedmioletnich, s. 17-21.
} 
czenia się w życie szkoły. W tym celu udzielali rodzicom informacji dotyczących kierunku pracy szkoły, warunków nauczania oraz bieżących problemów danej placówki edukacyjnej ${ }^{43}$.

Praca wychowawcza nauczycieli nie kończyła się na współpracy z rodzicami uczniów w tym zakresie. Kontynuowali ją oni bowiem w trakcie zajęć lekcyjnych, które musiały być przez nich starannie przygotowywane. Wybór odpowiedniego toku lekcji i przekazywanych treści, stosownie do wieku i poziomu intelektualnego uczniów, służył kształtowaniu u nich takich cech, jak: pracowitość, rzetelność, systematyczność, aktywność, samodzielność w wykonywaniu zleconych zadań. Niezmiennie jednak nauczyciele W codziennej pracy z dziećmi i młodzieżą musieli charakteryzować się autentycznością i pozytywnym stosunkiem do swojej pracy, a właściwie - powołania ${ }^{44}$.

Program wychowawczy nie był realizowany przez nauczycieli jedynie na prowadzonych przez nich lekcjach. Szansę na kształtowanie charakterów młodych ludzi dawały bowiem świetlice szkolne, samorządy szkolne i różnego rodzaju organizacje uczniowskie. Duże znaczenie miał też udział dzieci i młodzieży w uroczystościach organizowanych z okazji świąt patriotycznych ${ }^{45}$.

\section{Świetlice szkolne}

Zajęcia prowadzone przez nauczycieli w świetlicach szkolnych sprzyjały zacieśnianiu więzów przyjacielskich i koleżeńskich między uczniami, rozwojowi talentów, czytelnictwu. Bez wątpienia zatem pełniły funkcję wychowawczą. Przede wszystkim jednak były jednym ze sposobów organizowania dzieciom i młodzieży czasu wolnego, szczególnie w czasie ferii zimowych.

W tym właśnie okresie w świetlicach gromadzili się uczniowie, którzy nie chcieli ferii spędzać tylko w domu, lecz razem z kolegami i koleżankami ze szkoły. Tym bardziej, że program zajęć, mimo że zaplanowany jedynie na cztery godziny dziennie, był różnorodny i bogaty. Jeżeli pogoda sprzyjała uprawianiu sportów zimowych, to dzieci zjeżdżały na sankach, jeździły na nartach i łyżwach. W czasie niepogody natomiast uczniowie oddawali się lekturze ciekawych książek i czasopism, nauce i rozwijaniu umiejętności gry w szachy i warcaby, a także uczestniczyli we wszelkiego rodzaju grach o charakterze sportowym i edukacyjnym. Bardzo ważnym elementem organizowanych w zimie zajęć świetlicowych było przygotowanie zabawy choinkowej i widowiska jasełkowego. Przedsięwzięcie to angażowało do wspólnej pracy całą grupę uczniów gromadzących się w czasie ferii w świetlicy szkolnej. Bez wątpienia zatem sprzyjało kształtowaniu się w nich poczucia odpowiedzialności za realizację jakiegoś projektu i umiejętność

43 Ibidem.

44 Ibidem.

45 AZSG, Kronika Szkolna Publicznej Szkoły Powszechnej w Garbowie; AZSP, Kronika Szkolna Publicznej Szkoły Powszechnej w Przybysławicach; B. Sałęga, Schola Publica Garboviensis (odc. III), „Głos Garbowa" 12(1992), s. 4. 
pracy w zespole złożonym z kilku, kilkunastu, a nawet kilkudziesięciu osób. Wspomnieć bowiem trzeba, że dzieci chętnie przychodziły na świetlicę nawet przy silnych mrozach dochodzących do $-20^{\circ} \mathrm{C}^{46}$. Z tego powodu w świetlicy szkolnej w Przybysławicach zapewniano dzieciom drugie śniadanie, na które składały się bułka i kubek gorącego mleka $^{47}$.

Niestety zachowane dokumenty nie wspominają nic o funkcjonowaniu świetlic szkolnych przez pozostałą część roku. Nie można zatem wysnuć żadnych przypuszczeń co do tego, czy w ogóle działały i jakie zajęcia wówczas prowadzono.

\section{Samorządy szkolne}

Istotną rolę w realizacji programu wychowawczego spełniały samorządy szkolne. Zakładano je w każdej placówce edukacyjnej, niezależnie od stopnia zorganizowania ${ }^{48}$. Nadzór nad nimi powierzano natomiast nauczycielom ${ }^{49}$.

Samorządy szkolne z jednej strony pozwalały uczniom na wyłonienie spośród siebie osób, które reprezentowałyby ich przed kierownikiem szkoły i gronem pedagogicznym. Z drugiej strony dawały nauczycielom możliwość kształtowania u swoich wychowanków bardzo ważnych cech charakteru, z którymi powinni byli wejść w dorosłe życie. Należały do nich m.in. umiejętność samodzielnego podejmowania różnego typu działań, zdolność do włączania się w różnorodne inicjatywy społeczne, zaradność, zdyscyplinowanie $^{50}$.

Każdy samorząd szkolny funkcjonował w oparciu o statut samorządu szkolnego i regulamin postępowania uczniów w szkole i poza nią. Struktura władzy w samorządzie szkolnym była trójstopniowa i obejmowała władzę uchwałodawczą, władzę wykonawczą i władzę sądowniczą. Władza uchwałodawcza spoczywała w rękach tzw. walnego zebrania, które zatwierdzało różnego rodzaju regulaminy i wydawało decyzje odnośnie do wszelkiego rodzaju inicjatyw podejmowanych przez społeczność uczniowską. Władzę wykonawczą dzierżył zarząd ogólny, który czuwał nad przestrzeganiem wszelkiego rodzaju przepisów przyjętych na walnym zebraniu i ukierunkowywał prace samorządu. Władzę sądowniczą prezentował sąd koleżeński, który rozstrzygał niezałagodzone spory istniejące pomiędzy uczniami ${ }^{51}$.

Elementem wyróżniającym samorząd szkolny było pełnienie funkcji nadrzędnej w stosunku do różnego rodzaju organizacji uczniowskich, a więc wszelakich kół, sekcji

\footnotetext{
${ }^{46}$ AZSG, Kronika Szkolna Publicznej Szkoły Powszechnej w Garbowie; AZSP, Kronika Szkolna Publicznej Szkoły Powszechnej w Przybysławicach; B. Sałęga, Schola Publica Garboviensis (odc. III), „Głos Garbowa" 12(1992), s. 4.

47 AZSP, Kronika Szkolna Publicznej Szkoły Powszechnej w Przybysławicach.

${ }^{48}$ APL, Sygn. 35/542/15/-/2, Zespół: Szkoła Powszechna w Jastkowie, Kronika Szkolna.

49 AZSP, Kronika Szkolna Publicznej Szkoły Powszechnej w Przybysławicach.

${ }^{50}$ Ibidem.

${ }^{51}$ Ibidem.
} 
i działów. W praktyce oznaczało to składanie przez przewodniczących tych organizacji sprawozdań z ich działalności. Z uwagi zaś na to, że organizacje uczniowskie miały różny charakter i pole aktywności, można stwierdzić, iż samorząd szkolny obejmował zasięgiem swojego działania wszystkie sfery życia szkolnego ${ }^{52}$.

W skład samorządu szkolnego wchodziły samorządy klasowe (np. w szkole w Garbowie) lub gminy szkolne (np. w szkole w Przybysławicach). Istniały one w każdym oddziale szkolnym, a nadzór nad nimi obejmowali wychowawcy poszczególnych $\operatorname{klas}^{53}$.

Samorządy klasowe, podobnie jak samorządy szkolne posiadały własny statut i regulaminy, i tak jak one oparte były na trójstopniowym podziale władzy. Władza uchwałodawcza należała jednakże w tym przypadku do wszystkich uczniów w danym oddziale. Władzę wykonawczą reprezentował zarząd, w skład którego wchodziło pięciu członków. Władza sądownicza pozostawała $w$ rękach sądu polubownego złożonego z trzech osób ${ }^{54}$.

Głównym zadaniem samorządów klasowych było pełnienie dyżurów podczas przerw między lekcjami. Uczniowie dyżurni mieli obowiązek zwracać uwagę na postępowanie kolegów z klasy zarówno pod względem utrzymania porządku i czystości w klasie i na korytarzu szkolnym, jak i właściwego zachowywania się wobec nauczycieli i innych uczniów $^{55}$.

W szerszym zakresie aktywność przejawiały samorządy klasowe starszych oddziałów. Pod ich kierunkiem powoływano i nadzorowano działalność kół klasowych, prowadzono biblioteki klasowe i wydawano pisemka adresowane do młodzieży szkolnej ${ }^{56}$.

\section{Organizacje uczniowskie}

W dążeniach do osiągnięcia celów wychowania dzieci i młodzieży ważną kwestią było zakładanie i prowadzenie przez kadrę pedagogiczną różnego rodzaju organizacji uczniowskich. W ten sposób bowiem nauczyciele mogli mieć bezpośredni wpływ na harmonijny rozwój wychowanka we wszystkich sferach: intelektualnej, psychicznej, fizycznej, emocjonalnej, a nawet duchowej. Dzięki przynależności do samorządów szkolnych uczniowie przede wszystkim zapoznawali się z popularną w latach dwudziestolecia międzywojennego ideą spółdzielczości i zdobywali doświadczenie w zakresie organizowania i prowadzenia różnego rodzaju instytucji opartych na współdziałaniu grupy osób.

\footnotetext{
${ }^{52}$ AZSG, Księga Protokołów Nauczycielskich Konferencji Gminnych Gminy Garbów (1924-1935); AZSP, Kronika Szkolna Publicznej Szkoły Powszechnej w Przybysławicach.

${ }^{53}$ AZSG, Kronika Szkolna Publicznej Szkoły Powszechnej w Garbowie; AZSP, Kronika Szkolna Publicznej Szkoły Powszechnej w Przybysławicach.

54 AZSP, Kronika Szkolna Publicznej Szkoły Powszechnej w Przybysławicach.

${ }_{55}$ Ibidem; AZSG, Kronika Szkolna Publicznej Szkoły Powszechnej w Garbowie.

${ }^{56}$ Ibidem.
} 
Ponadto nabywali kompetencje społeczne, takie jak: zaradność, umiejętność współpracy, chęć podejmowania działań na rzecz innych ludzi ${ }^{57}$.

W szkołach powszechnych gminy Garbów funkcjonowały następujące organizacje uczniowskie: spółdzielnie uczniowskie, koła teatralne, chóry szkolne, drużyny harcerskie. Oprócz tego szkoła w Przybysławicach uruchomiła Sekcję Samopomocy Uczniowskiej, i Sekcję Rysunkową.

Spółdzielnie uczniowskie nosiły różną nazwę w poszczególnych szkołach. Spotkać się można zatem z określeniem tych instytucji jako kooperatywy szkolnej lub sekcji spółdzielczej. Nazwa była tutaj jednak najmniej istotna, gdyż niezależnie od niej działalność spółdzielni uczniowskich oparta była na podobnych zasadach, a w związku z tym zakres podejmowanych zadań był również zbliżony. Opiekunami spółdzielni uczniowskich byli kierownicy szkół ${ }^{58}$. Oni nadzorowali pracę tych organizacji, w ramach których funkcjonowały sklepiki uczniowskie i kasy oszczędności, przy czym obie instytucje były od siebie współzależne ${ }^{59}$.

Spółdzielnie uczniowskie opierały swoją działalność na statucie i regulaminie ${ }^{60}$, oraz na udziałach wpłacanych przez uczniów do kas oszczędności. Fundusze te bowiem stanowiły budżet przedsiębiorstw, jakimi były sklepiki uczniowskie. Pociągało to za sobą obowiązek prowadzenia księgowości i księgi udziałowców. W tej sposób dokumentowano wysokość zgromadzonych udziałów i oszczędności uczniów, środków przeznaczanych na zakup towarów i dochodów osiąganych z tytułu ich sprzedaży, oraz liczbę udziałowców. Zyski, które wypracowywano w ramach działalności sklepiku przeznaczano w połowie na dywidendy, a w połowie na dalszy rozwój tego uczniowskiego przedsiębiorstwa. W sytuacjach, kiedy szkoły zmagały się z brakiem środków finansowych na zakup mebli, książek, pomocy naukowych czy też zorganizowanie wycieczek, zarządy spółdzielni, za zgodą udziałowców dokonywały asygnaty pewnej kwoty pieniężnej na zaspokojenie tych potrzeb. Podobnie postępowano w przypadku akcji społecznych, mających na celu udzielenie pomocy materialnej ludziom potrzebującym lub wsparcie finansowe słusznej idei ${ }^{61}$.

Bez wątpienia można stwierdzić, że zarówno praca w sklepikach szkolnych, jak i posiadanie samych udziałów wyrabiały u uczniów zmysł przedsiębiorczości, uczyło inwestowania powierzonych im środków, a także odpowiedzialności za cudze mienie. Nie mniejsze znaczenie miały kasy oszczędności, dzięki którym uczniowie stawali się bardziej przezorni i potrafili spoglądać na życie w dłuższej perspektywie, niż okres kilku dni, tygodni czy nawet miesięcy. Istotną kwestią było też wyrobienie u dzieci i młodzieży umiejętności dostrzegania potrzeb innych ludzi.

\footnotetext{
57 Ibidem.

${ }^{58}$ Ibidem, AZSG, Księga Protokołów Nauczycielskich Konferencji Gminnych Gminy Garbów (1924-1935).

59 AZSG, Księga Protokołów Nauczycielskich Konferencji Gminnych Gminy Garbów (1924-1935); AZSP, Kronika Szkolna Publicznej Szkoły Powszechnej w Przybysławicach.

${ }^{60}$ Ibidem.

${ }^{61}$ Ibidem.
} 
W tym ostatnim duchu działalność swą prowadziła założona w 1931 r. w szkole powszechnej w Przybysławicach Sekcja Samopomocy Uczniowskiej. Jej działalność przypadła na lata wielkiego kryzysu gospodarczego, jaki dotknął Polskę w latach 1929-1935. Był to trudny czas również dla mieszkańców gminy Garbów, gdzie wciąż przybywało osób pozostających bez pracy. Rodzinom osób bezrobotnych brakowało środków na utrzymanie, nie stać ich było zatem na wyposażenie dzieci w podręczniki i przybory szkolne. Często nie posiadały one nawet ciepłej odzieży. W tej właśnie kwestii wsparciem służyła Sekcja Samopomocy Szkolnej ${ }^{62}$. Członkowie tej organizacji starali się zaopatrzyć swoich uboższych kolegów w potrzebne im rzeczy. W tym celu urządzali akcje społeczne wśród miejscowej ludności. Dzięki temu w każdym roku szkolnym pomocą w formie podręczników, zeszytów i piór, a także ubrania udawało się objąć nawet kilkunastu uczniów najbardziej potrzebujących takiego wsparcia ${ }^{63}$.

W 1935 r. zakończył się kryzys, więc sytuacja materialna wielu rodzin zaczęła się stopniowo poprawiać. Sekcja Samopomocy Uczniowskiej nie przerwała jednakże swej działalności na rzecz biednych uczniów. Czyniła to już jednak w ramach Koła Młodzieży Polskiego Czerwonego Krzyża, które również funkcjonowało na terenie szkoły w Przybysławicach. Połączone organizacje zaopatrywały apteczkę szkolną, udzielały pierwszej pomocy w nagłych wypadkach i zajmowały się opieką sanitarno-higieniczną na terenie szkoły. Ponadto w ramach swoich obowiązków uczestniczyły w akcjach dożywiania dzieci oraz zdobywania funduszy na zakup odzieży, podręczników i przyborów szkolnych ${ }^{64}$.

Problem braku podręczników szkolnych dla najmłodszych uczniów starali się rozwiązywać absolwenci szkoły w Przybysławicach, którzy zawiązali na jej terenie Sekcję Rysunkową. Za cel swojej działalności obrali m.in. kopiowanie ilustracji z elementarza Falskiego, dzięki czemu udawało się niewielkimi kosztami stworzyć podręcznik dla dzieci pochodzących z niezamożnych rodzin ${ }^{65}$.

Wychowanie społeczne stanowiło bardzo ważny element w kształtowaniu postawy dzieci i młodzieży wobec różnych problemów życiowych. Równie istotne było także wychowanie artystyczne. W tym celu w każdej szkole zakładano kółka teatralne. Podobnie jak inne organizacje uczniowskie one również posiadały zarząd, w obowiązki którego wpisane było opracowanie harmonogramu pracy na cały rok szkolny. Kółka teatralne zajmowały się przede wszystkim pisaniem scenariuszy, przygotowywaniem scenografii i wystawianiem dzieł znanych poetów ${ }^{66}$. Przynależność do tego rodzaju organizacji dawała możliwość rozwijania swoich talentów wszystkim dzieciom uzdolnionym artystycznie. Swoje miejsce znaleźć tu bowiem mogli zarówno przyszli aktorzy, jak i plastycy i muzycy. Zwrócić też trzeba uwagę na to, że praca nad przedstawieniem wymagała nie-

\footnotetext{
62 AZSP, Kronika Szkolna Publicznej Szkoły Powszechnej w Przybysławicach.

${ }^{63}$ Ibidem.

${ }^{64}$ Ibidem.

${ }^{65}$ Ibidem.

${ }^{66}$ Ibidem.
} 
samowitej dyscypliny, odpowiedzialności i szacunku tak w stosunku do grupy teatralnej, jak również do widzów.

Podobne cechy charakteru kształtowały się u członków chórów szkolnych, które często stanowiły chlubną ozdobę i podstawę wszelkiego rodzaju uroczystości szkolnych, gminnych i kościelnych. Zaznaczyć jednak należy, iż organizacje te funkcjonowały jedynie w szkole garbowskiej i przybysławickiej, a ponadto skupiały głównie uczniów czterech najstarszych klas, przy czym większą część chórów stanowiły dziewczęta ${ }^{67}$.

Wszelkiego rodzaju kompetencje społeczne i talenty artystyczne stanowiły istotną część całościowego charakteru młodego człowieka. Nauczyciele szkół gminy Garbów nie zaprzestali jednakże na samym uspołecznieniu swoich uczniów. Starali się wpoić im elementy wychowania państwowego i patriotycznego.

Niewątpliwie duże znaczenie w tym zakresie odgrywało harcerstwo. Drużyny harcerskie istniały w 7-klasowej szkole w Przybysławicach i Garbowie. W pierwszej placówce w 1932 r. utworzono dwie drużyny harcerskie: męską i żeńską ${ }^{68}$. W Garbowie rok później powstała drużyna żeńska złożona z 22 dziewcząt. Opiekę nad organizacją powierzono Helenie Traczównie ${ }^{69}$.

Uzupełniającą rolę w wychowaniu patriotycznym spełniało uczestnictwo uczniów w obchodach świąt państwowych, mających zarówno charakter uroczystości gminnych, jak i szkolnych. Każdego roku gmina Garbów organizowała obchody rocznicy Powstania Styczniowego, rocznicy Powstania Listopadowego, rocznicy uwalenia Konstytucji 3 Maja, rocznicy odzyskania niepodległości określanej mianem Święta Niepodległości oraz obchody imienin Józefa Piłsudskiego ${ }^{70}$. Główne uroczystości odbywały się zazwyczaj w Garbowie, a uczestniczyła w nich cała społeczność gminna. W harmonogramie każdych obchodów znajdowały się: nabożeństwo kościelne z kazaniem okolicznościowym, defilada ze sztandarami, pochód oraz akademia ${ }^{71}$.

Uroczystości gminne dotyczyły ważnych świąt państwowych. Społeczności szkolne dążyły jednakże do uczczenia pamięci innych ważnych wydarzeń historycznych i wielkich Polaków. Uroczystości te miały charakter mniej podniosły i odbywały się na terenie szkoły. W ten sposób 1 listopada każdego roku upamiętniano bohaterów narodowych. Począwszy zaś od 1936 r. 19 marca i 12 maja organizowano uroczystości wspomnieniowe dotyczące osoby Józefa Piłsudskiego - „Wielkiego Wodza”. Urządzano również obchody ku czci poetów polskich ${ }^{72}$.

${ }^{67}$ Ibidem.

${ }^{68}$ Ibidem.

${ }^{69}$ AZSG, Kronika Szkolna Publicznej Szkoły Powszechnej w Garbowie; B. Sałęga, Schola Publica Garboviensis (odc. III), „Głos Garbowa”, 12(1992), s. 4; M. Kierczyńska, M. Suszkiewiczowa, Wspomnienie o Helenie Traczównie, „Głos Garbowa” 11(2002), s. 4-5.

${ }^{70}$ AZSG, Kronika Szkolna Publicznej Szkoły Powszechnej w Garbowie; AZSG, Księga Protokołów Nauczycielskich Konferencji Gminnych Gminy Garbów (1924-1935); AZSP, Kronika Szkolna Publicznej Szkoły Powszechnej w Przybysławicach; B. Sałęga, Schola Publica Garboviensis (odc. III), „Głos Garbowa” 12(1992), S. 4.

71 AZSP, Kronika Szkolna Publicznej Szkoły Powszechnej w Przybysławicach.

${ }^{72}$ Ibidem. 


\section{Zakończenie}

Organizacja nauczania powszechnego na terenie wiejskiej gminy Garbów stała na dość wysokim poziomie. W dość krótkim czasie udało się bowiem utworzyć sieć kilkunastu szkół powszechnych, z których jedna - w Garbowie - przekształcona została z istniejącej w latach zaboru rosyjskiego szkoły elementarnej, a kilka innych powstało na gruncie funkcjonujących wcześniej szkół prywatnych zakładanych głównie przez właścicieli majątków ziemskich.

Warunki nauczania z pewnością były skromniejsze niż w bogatszych szkołach miejskich. Świadczy o tym fakt pozyskiwania funduszy na zakup wyposażenia sal lekcyjnych i pomocy naukowych przez urządzanie różnego rodzaju loterii, czy też przedstawień szkolnych. Niemniej nauczyciele dokładali wszelkich starań, aby spełnić wymagania władz oświatowych $\mathrm{w}$ celu realizacji programu nauczania $\mathrm{i}$ wychowania $\mathrm{w}$ polskich szkołach powszechnych.

Staranne przygotowywanie się do zajęć lekcyjnych skutkowało lepszym przyswojeniem przez uczniów przekazywanej wiedzy i szybszym nabywaniem niezbędnych umiejętności. Powoływanie różnego rodzaju kół i sekcji uczniowskich pozwalało na wywieranie bezpośredniego wpływu na kształtowanie się charakteru wychowanka we wszystkich jego aspektach.

Nie bez znaczenia dla osiągnięcia sukcesu dydaktyczno-wychowawczego była postawa nauczycieli szkół gminy Garbów, a przede wszystkim ich stosunek do własnych obowiązków, do życia i do drugiego człowieka. Pamiętano bowiem o tym, że nauczyciel powinien stanowić autorytet i wzór postępowania dla swoich uczniów, a zarazem wychowanków.

\section{Bibliografia}

150 lat Szkoty w Garbowie, Garbów 2010.

Archiwum Akt Nowych w Warszawie, Sygn. 712, Zespół: Związek Zawodowy Cukrowni, Cukrownia Garbów - Szkoła.

Archiwum Państwowe w Lublinie, Sygn. 35/525/0/3146, Zespół: Dyrekcje Szkolne, Akta Lubelskiej Dyrekcji Szkolnej, Naczelnik Szkoły w Garbowie, gminy Garbów w powiecie NowoAleksandryjskim, 1865-1866.

Archiwum Państwowe w Lublinie, Sygn. 35/542/15/-/2, Zespół: Szkoła Powszechna w Jastkowie, Kronika Szkolna.

Archiwum Państwowe w Lublinie, Sygn. 35/732/0/2/53,Zespół: Inspektorat Szkolny w Puławach, Akta Szkoły Podstawowej w Leścach, 1944-1950.

Archiwum Państwowe w Lublinie, Sygn. 35/732/0/2/90, Zespół: Inspektorat Szkolny w Puławach, Akta Szkoły Podstawowej w Woli Przybysławskiej.

Archiwum Zespołu Szkół w Garbowie I, Kronika Szkolna Publicznej Szkoły Powszechnej w Garbowie.

Archiwum Zespołu Szkół w Garbowie I, Księga Protokołów Nauczycielskich Konferencji Gminnych Gminy Garbów (1924-1935). 
Archiwum Zespołu Szkół w Przybysławicach, Kronika Szkolna Publicznej Szkoły Powszechnej w Przybysławicach.

Balcerek M., Rozwój opieki nad dzieckiem w Polsce w latach 1918-1939, Warszawa 1978.

Danielski M., Ustawodawstwo Szkolne i Prawo Nauczycielskie, Lwów-Warszawa-Poznań 1932.

Dekret o obowiązku szkolnym z 7 lutego 1919 roku (Dz.U. 1919 nr 14, poz. 147).

Dolnośląska Biblioteka Cyfrowa, Statut Publicznych Szkół Powszechnych Siedmioletnich.

Grabowska W., Szkolnictwo powszechne w Polsce w latach 1932-1939, Wrocław-Warszawa-Kraków-Gdańsk 1976.

Kierczyńska M., Suszkiewiczowa M., Wspomnienie o Helenie Traczównie, „Głos Garbowa” 11(2002), s. 4-5.

Kula W., Wspomnienia o Marianie Gietce w 55. rocznice śmierci, „Głos Garbowa” 6(2004), s. 11 .

Kula W., Wspomnienia o Marianie Gietce w 55. rocznice śmierci, Wspomnienia Bronistawy Dzierżyc, „Głos Garbowa” 7-8(2004), s. 13.

Mazur P., Szkolnictwona Lubelszczyźnie w świetle prasy lokalnej, 1918-1939, Lublin 2004.

Sałęga B., Schola Publica Garboviensis (odc. III), „Głos Garbowa” 12(1992), s. 4.

Sałęga B., Schola Publica Garboviensis (odc. IV), „Głos Garbowa” 1(1993), s. 5.

Stępniak H., Szkoła w Przybystawicach (odcinek I), „Głos Garbowa” 10(1994), s. 3.

Ustawa z dnia 11 marca 1932 r. o ustroju szkolnictwa (Dz.U. $1932 \mathrm{nr} 38$ poz. 389).

Ustawa z dnia 17 lutego 1922 r. o zakładaniu i utrzymywaniu publicznych szkół powszechnych (Dz.U. $1922 \mathrm{nr} 18$ poz. 144).

Ustawa z dnia 4 czerwca 1920 roku o tymczasowym ustroju władz szkolnych (Dz. U. z 1920 r. Nr 50, poz. 304).

Wartacz M., Kilka słów o Gutanowie - dawnym i współczesnym, odc. I, „Głos Garbowa” 1(1997), s. 6-7.

Wartacz M., Kilka słów o Gutanowie - dawnym i wspótczesnym, odc. II, „Głos Garbowa” 2(1997), s. 6-7.

Wartacz M., Tomasz Wincenty Grabowski, w: Siedziby ziemiańskie w krajobrazie ziemi garbowskiej, pod red. H. Stępniak, Garbów 2008, s. 291-298.

Wójcik R., Historia Cukrowni „, Garbów”, Lublin 2010.

http://www.jastkow.pl/index.php?option=com_content\&view=article\&id=66\&Itemid=91, (13.03.2012). 
